\title{
EDUCATIONAL JUSTICE FOR DIVERSIFIED NEPALI CHILDREN
}

Bidya Nath Koirala *

Abstract

Contradictions are the lived realities of the human beings.

They are more so with the people of Nepal who live with multiplicities, modernities, and post-modernities. These multiplicities have come from different roots such as language

diversities; caste diversities; class diversities; religious pluralities; ascribed, described, and aspirant gender roles; lived and intended power relations with "bierarchicals" caste groups and communal ethnic groups; and pedagogical variations that grew out in the country and that we imported from the West. This indicates that we have pluralities to be managed from different lenses. Reflection on personal back up,

putting legs on others' shoes, listening to others, and creating mosaic are some of the measures that are to be nurtured if we want to ensure educational justice to the diverse groups of people.

\section{Lived Context}

Culturally I learnt to live in two worlds, culture of ahaum brahmasmi (I am the universe) and culture of sarbasukhaya (happiness of all). How to ensure happy interface between these two worlds: world of I and world of happiness of all (we). Religion taught me to give up "I" and blur it with universe. At the same time it taught me to socialize my "I" within kin, clan, and religious group. My way of blurring "I" with universe made me philosopher and my way of confining myself within kin, clan, and religious group made me "practical person". As a philosopher I could not put my legs in other shoes and feel their problem because I am afraid of being involved in sansarik duniya (worldly people) and loosing my connection with brahma (the cosmic self). My position between brahma and sansarik duniya (civilized world) made me confused. Out of this confusion I have to ensure justice to those who opt for brahma and those who opt for sansarik duniya. In the Hindu mythological language I have to deal with both nibriti (detachment from the world) and prabriti (attachment with the world) marga (path). In other words I have to address the needs of diversified groups of people with their mythological orientations. Here the question comes, do we have the provision of education for these groups of people? The answer is "no". This "no" tells me that I have to deal with various forms of path holders between prabriti to nibriti marga of different religious faith (Baral, 1993).

As a sansarik byakti (worldly person) I encountered different forms of diversities. These diversities are also manifested in the form of gender. From the gender point of view, I as a man learnt to be refrained from domestic work. However, there are some ethnic cultures which did not comply with my context. This made me again confused, whether I have to retain my traditional "maleculture" or go for the culture of other ethnic groups whom I treated as "inferior" for generations or they treated me as "superior" for years (Hill, 2003). This cultural diversities are manifested everywhere in

\footnotetext{
* Faculty of Education, Tribhuwan University.
} 
Nepal. For example, Muslim man is different from Sherpa Man from gender perspective the former being hard to women and the later being friendly and open to them. This implies that I have to deal with various forms of diversities that are found in the gender continuum (UNESCO, 2003) of gender blind, gender aware, gender sympathetic, and gender sensitive people of Nepal.

Following the lived track of my parents I learnt to be sexist. In the language of feminist, I learnt to be protectionist male. At the same time, I found some of the women comfortable to be protected and others to be equalitarian. Between these two polar forms of women, I found others as well who were willing to be protected in one occasion and be equalitarian on the other. This situation gave me other forms of diversity to deal with: the diversity that is built on between woman and man.

In my childhood, I often heard that women should cultivate soft-spoken and servitude personality. Women also followed the "cultural curriculum" unquestioningly and/or silently. This "culture of silence" (Freire, 1968) encouraged me to be a "man" over "woman". In the words of gender analyzer, I hold patriarchic knowledge to be superior to women. At the same time I found old women as "man" to oppress younger women. But there were some others in the village that followed matriarchy. In this sense, I found different forms of power relations among parents and their children. This implies that as a teacher I have to deal with the children raised in different power relations at their home culture.

My peasantry life style taught me to be unequal with the people of different forms of functional, caste, and ethnic groups. As a Brahman I learnt to get respect from others and thought others' as "inferior" to me. So did the caste and ethnic groups of people to others. This "functional" and/ or "reproductive nature" (Carney, 1999) of my peasantry life taught me that there are functional, caste, and ethnic hierarchies in Nepal.
These hierarchies are oriented and reoriented by the contemporary hegemony (Nirnaya Sindu, the Hindu code of conduct, Manusmriti; \& Yagyabalkyasmriti). This reality of my life implies that I have to deal with caste diversities that range from touchable, water touchable, and untouchable groups of people. In other words I have to address the psychology and sociology of all forms of caste groups and their internal relationship. At the same time I have to develop educational programs to ensure justice for all forms of functionally oriented people. In other words, I have to tell to the people that blacksmithy and priestly jobs are equal and they deserve equal status which is different from what I learnt in my peasantry life. Similarly, I am supposed to deal with people of diverse ethnic background who in one or in other way are ethnicity conscious. Amidst this ethnic consciousness I have to balance my caste consciousness as well which persistently told me that I am Arya (intellect), and as an Arya, I have to deal with intellects with intellectual way; with non-intellectuals with nonintellectual way. This is where I have to address ability groups of various orientations.

Critical literature taught me that none of the groups of people is inferior but different. And they are different because of their cultural, social, economic "capitals" and "habitus" (Bourdieu, 1990). This knowledge made me think of cultural values towards education (Llieva, 2003) because there are some cultural groups who value education more than others (PRA report of Betkuiya VDC, Rupandehi district, 2004). The reverse is true with the people of other ethnic and caste groups' culture. This knowledge taught me to do cultural analysis. Cross-cultural reports (Nateras, 2003) reiterated my knowledge once again that I have to deal with different cultural capitals, social capitals, and economic capitals.

In the hill where I was born and raised, I found people speaking Tamang, Newar, Magar, Hayu, Majhi, and Nepali within 4 square kilometers. The analysis of census data (2002) reconfirmed 
my lived reality of language diversity when it showed that every 1000 person there are 20 ethnic/caste groups of people in Nepal and language variation is already attached to it. This situation made me think about pedagogical approach to address different forms of diversities (Silut, 2003; Taggart, 2002) including language diversity. Simultaneously my lived context told me to develop a lingua franca and help improve and protect their language as well. In other words, the context taught me to be multilingual and multicultural teacher. But the school on the other hand taught me to be monolingual and mono-cultural. Amidst these diversified linguistic culture I found some of the ethnic/ linguistic people offensive against Nepali, the official language of Nepal. This implies that I have to deal with language diversity and manage the ego of different language groups (Savva, 2002).

In my school I found disabled friends. Some of them were physically challenged and others were mentally challenged (MOES, 1997). These "challenged people" were valued differently at home and their study place. In their houses, they were the children born from the curse of the previous birth and in the school they were considered as different people. Besides, these "challenged people" had different needs and interests to be served through educative process. It is where I have to manage disability diversity in school and the community.

Culturally a Nepali learnt to be feudal through his/her lived structure even if s/he belongs to proletariat income bracket. These "hidden feudal", along with real feudal, became instrumental in perpetuating child labor. In the Marxist terminology, these production- detached elites (Mathews, 1980) and their bourgeois Gurus justified the existence of child labor from "functional perspective". Others on the other hand criticized the state and advocated the need of child rights to education. These various groups of people showed different forms of diversities inside child labors. Their earning and job status showed another forms of diversities such as worst forms of child labor, child labor and child worker.

Political unrest and intolerance yielded "war victims." These victims belong to different categories. Some of them need counseling for a day; others' need therapeutic support for couple of months. The third groups of people require rehab. As a teacher I have to deal with these diversities no matter which warring party (Maoist or Government) traumatized or displaced children. Domestic victims, harassed children, pampered children, children with abnormal psychology are some of the other groups who require pedagogical support to be at par with their normal counterparts. In other words I have to address these diversities as well.

Children with different skills come to my class. Some of these children feel comfortable to learn from me because of their "skill compatibility" and others fail because of their learning style, "skill incompatibility", and many other difficulties. As a teacher I have to deal with these multiplicities.

Because of my sociological orientations, I came to know that there are multiple diversities with a single student. For example, a girl child can be a Dalit (socially untouchable groups of people), disable, a war victim. As a teacher I have to address multiplicities at a time. For instance I can analyze her as a girl child of patriarchic society or "functional society". She may also be analyzed as a member of "standpoint believer." From Dalits' point of view, she might hold the knowledge that she is triply disadvantaged person, as a war victim, as a girl, as a disable, and as a Dalit. This implies that I have to deal with multiple issues within a person as well.

\section{Issue of Pluralism}

Pluralism is my practical reality. These realities as I mentioned before are manifested in different forms in the classroom. But how did I manage these diversities? Again my cultural practice 
taught me to apply hanuman chalisa (praise and encourage for desired end). In the words of development workers, I learnt appreciative inquiry of multiple Gods and Goddesses. To make it more clear I learnt easy shift of my pray: start from the pray of Ganesh, go for Devis, Mahadev, and end with Vishnu or any other ways to begin and end my pray. What does it signify? From the "stability closure" I learnt to be unstable devotee. From the "pluralist closure", I learnt to please every God and Goddess for me. From the critical closure, I learnt to be enslaved in the feudal culture. And from the "functionality closure" I learnt assimilation and acculturation.

Did I practice my religious approach to hanuman chalisa in the classroom? My reflection tells me "no". In fact I did not appreciate my Dalit student for his/her parental skills of making pots, tailoring, bamboo work, singing, dancing, woodwork, and many others. Then the question comes, why did not I apply my knowledge of hanuman chalisa in teaching Dalits? Why did not I apply my language shifting approach of praying (from Sanskrit to Hindi, and to Nepali) to teach in the multilingual classes? Why did I forget the knowledge of Dattatraya who had 24 Gurus and two of these were a girl child and a Dalit? Why I always tried only to be Guru? Why did not I find Gurus from my classrooms? These why questions taught me that I am "internal colonizer" (Carnoy, 1984) who deposits his/her knowledge to the students (Freire, 1968). In this sense I became oppressor of the students, power holder in the political sense, and disguised state apparatus in Gramsci's understanding.

The discussion above yielded an issue of linking cultural practice in classroom teaching. This is not the new practice for me because culturally I taught my students to be pundit. The way I taught supported my practice. But I failed to reproduce my "pundit type culture" in applying hanuman chalisa. Why I became selective in applying hanuman chalisa? Is this the ego that restricted me to apply it? Or is it the ignorance about my doing? Is this the fear of being "dominated" by my students? Is this my "apartheid approach" against students? Is this my "hidden bias" that students are "inferior to me" to learn with them?

I witnessed "imported ideas" with dollar support to address plurality. For example, I went through UN approach to address girls and women's issues in the 1970s; language diversity management approaches of different INGOs and NGOs in the late 1980s; critical and hanuman chalisa approach of the development partners in the 1990 s, and integrated and inclusive approach to ensure marginalized people's representation in education in the 2000s. Were these dollar supported "imported ideas" able to produce opinion leaders at the grassroots? Were they creating hegemony at the apex of education structure? Were they not been able to link their concerns with my lived culture? Were they been welcomed by my authorities to "eat up" their dollars only? These questions themselves yielded some issues. For instance, do we follow "dollar supported imported ideas" blindly? Or we look for our lived pluralities to address the concerns of "dollar supported ideas?" Why did not I tell to the "dollar maliks" (master/mistress) to go to learn from our lived diversities to answer their concerns? Why did not I apply Sherpa culture to address gender issue? Why did not I apply Tharu culture to promote self-governance and cleanliness? Why did not I make people of different cultures and faiths to be reflective about their lived culture? Why did not I develop different closures to let people be reflective about their approaches to multiplicity management? Why did not I develop a checklist to help my colleagues reflect upon their own doings in addressing diversity? These unanswered why questions are some of the issues to be addressed.

Traditionally I valued others knowledge and hence learnt to be follower. The position that I got made me "instructor" even in the areas that I never knew. Here the questions popped up 
why did not I learn outsourcing for classroom teaching? Why did I make my students rely on others knowledge or make them able to explore his/her knowledge? In other words, why did not I promote teacher research student research and collaborative research with community elites to address my classroom diversities (Jackson, 2002 Griffiths, 1998)? Why did I look for teacher training opportunity which did not change my attitude? Why could I believe that only the socalled experts are knowledgeable who hardly face the diversities that I am facing in my classroom? My questions to myself could make me teachers, and my community-elites researchers. But why did not I professionalize myself and come up with new ideas to address the lived diversities through educative process? These questions yielded the issue of making teacher/student/colleague researchers. How can we do it? What could be the role of teachers' organizations and teacher training institutions in it? What a teacher should opt for, from whom, and when? These questions require issue discussion sessions through different perspectives to address research based classroom diversities.

As a teacher I learnt to teach textbooks and learnt to handle textbooks in the training program. But I did not get chance to update me with additional knowledge of the country and the abroad. Even my supervisor gave me the stale dishes under his/her "recurrent technical backup". Thus as a teacher I learnt to read textbook and ask students read the same textbooks. What a poor thing that I did? I never asked educationists about the use of textbooks for teachers. Otherwise they would let me know that textbooks are made for students and reference books are prescribed for teachers. Why did not the educationists yelled at teachers against their use of textbooks in the class? Why did not they tell teachers and students to develop textbooks in their own diversity setting? These "why questions" are to be answered from different perspectives especially in the use of textbooks by teachers to address classroom diversities.
As a professional I knew that people of different political ideologies advocated democratic values. But what have been their "democratic values" to be shared and to be practiced to address classroom diversities? For example, freedom of choice is the democratic ideal but the "Muslim democratic values" did not tolerate Salman Rushdi's book Satanic Verses. Here the plurality is unattended. The same case applies to the students' strike in Nepal. Only a few students go for strike without any compensatory learning package for the lost study days. Others follow the strikers for fear of their "bulling nature". This implies that I have to discuss about "democratic values" of each political party. At this point, the question is why did not I hold workshop with political party leaders to discuss and come up with shared meaning of "democratic value" to be applied in my diverse groups of students? Why did not I convince the striking students regard others "democratic value" upon theirs? Why did not I make non-striking students raise their voice about their democratic values? These questions help generate different perspectives to look at educational issues related to classroom diversities. The following are my initial approaches to address the aforesaid pluralities.

\section{Approach to Egalitarian Management}

\section{(a) Exploration of individual status}

Awareness, sensitivity, integration, and inclusion line up in a continuum for diversity management. In the awareness phase I can think of what it is at least at the theoretical level? How many diversities I have to deal with? How can I deal with them? Where can I get resources? To know these questions and try to find out the answer at mental level is awareness. But mere awareness may not translate the idea into action and yet it is something to jump on diversity management board. This situation demands my step on sensitivity continuum. Am I sensitive about these issues? If I am, is there any change in my communicative language? How did I notice 
it? How I let others notice about it? Did I ever work to address the diversity that I'm sensitized with? Basically these are the practical questions that demand answer from me. These practical answers look for integration efforts. These efforts can be manifested in the form of physical representation of diverse group in discussion and dialogue about their problems. The next form is their efforts to improve their language, culture, identity, and status. This makes me busy in research and action. But at this point as well I may be dealing diversities one by one. In other words, sometimes I discuss gender diversity and in other times I look for language diversity. In the last continuum of diversity management, I examine and understand diversity from different perspectives. For example, I may start the issue of disabled child. What types of disability? What are the problems associated with this/these types of disabilities? I will explore whether that child is fast or slow reader, ethnic or caste group, language and dialect group, male or female? All these explorations will help me to figure out his/ her individual problem and deal accordingly.

\section{(b) Development of individual profile}

Progress and regress are normative. These norms can be derived from different sources. But for inclusive justice (Slee, 2001) to the diversified group, I will develop individual profile of my student. In this profile, I'll write individual's progress and regress in qualitative and quantitative forms. The profile will also have local, national, and international standard that are opted for. My student will thus be able to figure out where s/he stands on through this parameter. For example, one can know about his/her gender assessment level, caste understanding level, disability reading level, and other levels. There will be two columns in each aspect of assessment. My student will fill one column and I will fill the next column. This parameter will help my students learn his/her ability by himself/herself.

\section{(c) Discussion sess ions for contradiction management}

Sankhya school of Hindu thought taught me the existence of dual force, spirit and nature with me: the first being the Purush (God) and the second the Prakirti (women/nature). This school of Hindu religion taught me to manage these contradictions in life. So did Charwak who advocated for the happiness in material world. This Charwak philosophy of Hindu school gave me the closure that material life is everything. This teaching helped me contradict with Sankhya's thought of Purush. In other words I managed the contradictions in a different way. Karl Marx who brought materialistic perspectives of life taught me about class struggle. His theory helped me understand and manage social contradictions. The discussion implies that I as a teacher have to manage personal contradictions at the individual; social contradictions at the students, teachers, and community level; and emotional contradictions between my professional requirements and individual requirements.

How can I manage my contradictions in life? As a teacher I am supposed to discuss about these contradictions with my colleagues. But because of their egoism and/or my fear of being humiliated by others I cannot share my contradictions with them. It is where I need contradiction management sessions. I will organize these sessions within school and inter school settings.

\section{(d) Identification of commonality and point of departure}

Lived context taught me eastern knowledge and acquired knowledge pushed me to learn western culture. Amidst these cultural worlds I have to find out commonality and point of departures in every aspect of life. For instance, I learnt to maintain silence while eating in my lived context. But the western culture taught me to go for over lunch meeting. These two cultural knowledge systems made me think about the commonality and point of departure. There are many other knowledge systems that are to be understood 
by the teachers like me. In this context, I will make my teachers, students and elites able to analyze eastern and western cultures and find the commonality and point of departures.

\section{(e) Internalization of equality concept}

Hierarchical society teaches me to be unequal which contradicts with egalitarian approach to equality (Sobkin, 2000). Consequently I learnt to be hierarchical in language, dealing, and thinking. This made me think of someone to be superior and inferior. But the knowledge of inclusion and integration taught me to be equal. Here I am supposed to eliminate my ego and let others do the same. In other words, I will develop and implement programs to help internalize the idea of equality over the hierarchical society.

\section{(f) Initiation of "if I were you" campaign}

Situating someone in others problem is one of the ways to capture others sentiment. This can be done by introducing "if I were you campaign". Following this campaign, I will help students feel others problems. This approach will make my students sympathetic as well as empathetic to others issues. Dialogue sessions, field research, and observation could be my ways to help students feel others problem.

\section{(g) Sharing sessions}

Every individual is different in identifying and solving the problems. Professionally I am supposed to share them with my friends and colleagues. But I was not tuned that way. In this context, I will organize in-house periodic sharing sessions to discuss about encountered problems and solutions made. This reciprocal learning session will be helpful to bring classroom context to the floor, and seek national and international solutions as well.

\section{(b) Introduction of guidance and counseling services in school}

Students face many difficulties. These difficulties can be of varied nature that ranges form personal to social and technological. Many of these difficulties can be resolved through individual and group guidance and counseling. Others can be solved by therapeutic approaches. Keeping these things in mind I will develop my teachers as teacher counselors. At the same time I will consult with the private agencies to run therapeutic programs for the referral students.

\section{(i) Listening and thinking more than instructing}

As a victim of pundit culture, I learnt to instruct others. But the democratic ideals challenged my way of instructing people. And hence I adapted reflective approach to learning which led me to listen and think more than to instruct others. The day will come that my process of doing things may make me "democrat" of any political belief. At the same time it will help me encourage students to be self-learner and me as teacher researcher.

\section{(k) Changing pedagogical values and style}

The reflection over the reflections helped me learn that I cannot ensure all kinds of justice to my students. But I can make them able to analyze things from different perspectives and let them find out "good questions" to be answered through out their life. I will obtain such "good questions" by changing my teaching approach. In other words, I will link knowledge of the East and the West and let students think for their knowledge. Similarly, I will follow inclusive approach to teaching where I'll be discussing an issue from different perspectives. For example, I will discuss the issue of poverty from Rostow's development theory, Marxist theory, dependency theory, standpoint theory, cultural theory, and the Eastern philosophy and then let student think for his/her own theory. In this process, I will think of issues to be made inclusive, the issue of gender, caste, ethnicity, disability, child labor, language, cultural values, and professions. I may not be able to discuss all these issues simultaneously but can ask my student to think over these issues throughout their lives. 


\section{References}

Baral, B. (1993). Features of Hindu social organization (in Nepali). ( $2^{\text {nd }}$ edition). Kathmandu: Sajha Prakashan.

Bernstein, B. (1996). Class and pedagogies: Visible and invisible. In A. H. Halsey et. al., (Eds). Education, culture, economy, and society. New York: Oxford University Press.

Bourdieu, P. (1990). The logic of practice. London: Stanford University Press.

Carney, S. (1999). Sociology of education. A paper presented for discussion at Royal Danish School of Educational Studies, Denmark.

Carnoy, M. (1984). The state and political theory. New Jersey: Princeton University Press.

Faculty of Education, Dean's Office (2002). Education for social justice (in Nepali). Kathmandu: Author.

Freire, P. (1968). Pedagogy of the oppressed. New York: The Seabury Press.

Griffiths, M. (1998). Educational research for social justice: Getting off the fence. Buckingham: Open University Press.

Hill, R. J. (2003). Turning a gay gaze on citizenship, social orientation and gender identity: contesting/ed terrain. In C. Medel-Anonuevo and G. Mitchell (Eds.). Citizenship, democracy, and lifelong learning. Philippines: UNESCO Institute for Education.

Jackson, P. (2002). Life in classroom. In A. Pollard and J. Bourne (Eds.). Teaching and learning in the primary school. London: Routledge.

Llieva, E. (2003). An intercultural program from a Balkan perspective. In C. Medel-Anonuevo and G. Mitchell (Eds.). Citizenship, democracy, and lifelong learning. Philippines: UNESCO Institute for Education.
Mathews, M. R. (1980). The Marxist theory of schooling: $A$ study of epistemology and education. New Jersey: Humanities Press.

Ministry of Education, Master Plan Team (1997). The basic and primary education master plan. Kathmandu. Author.

Nateras, M. M. (2003). Fostering cross-cultural relations to promote civic participation. In C. MedelAnonuevo and G. Mitchell (Eds.). Citizenship, democracy, and lifelong learning. Philippines: UNESCO Institute for Education.

Savva, H (2002). Bilingual by rights. In A. Pollard and J. Bourne (Eds.). Teaching and learning in the primary school. London: Routledge.

Silut, S. J. (2003). The role of national languages in promoting democracy in Africa. In C. Medel-Anonuevo and G. Mitchell (Eds.). Citizenship, democracy, and lifelong learning. The Philippines: UNESCO Institute for Education.

Slee, R. (2001). Social justice and the changing directions in educational research: the case of inclusive education. Inclusive education. Vol. 5, No. 2/3.

Sobkin, V. (2000). Education and the problem of social inequality in Russia. Inclusive education. vol. 5 , No. $2 / 3$.

McTaggart, R. (2002). Involving the whole staff in developing a math curriculum. In A. Pollard and J. Bourne (Eds.). Teaching and learning in the primary school. London: Routledge.

UNESCO (2003). Gender and education for all: The leap to equality. Paris: UNESCO Press. 